\title{
An Appraisal of California's No-Fault Divorce Law
}

\author{
Herma Hill Kay†
}

California's no-fault divorce law became effective in $1970 .^{1}$ As the nation's first "pure" no-fault divorce law, it reinoved consideration of inarital fault froin the grounds for divorce, ${ }^{2}$ froin the award of spousal support, ${ }^{3}$ and froin the division of property. ${ }^{4}$ The Act retained fault as a relevant factor during marital dissolution proceedings on ouly two issues. First, if necessary, fault could be used to prove the existence of one of the no-fault grounds for dissolution: irreconcilable differences that had caused the irremediable breakdown of the marriage. ${ }^{5}$ In addition, fault was admissible on the question of child custody to show that parental custody would be detrimental to the child. ${ }^{6}$ The no-fault law treated post-marital fault as determinative on one aspect of post-dissolution inodification proceedings: in the absence of an agreeinent to the contrary, spousal support might be revoked or modified upon a showing that the supported spouse was hiving in nonmarital cohabitation with a third person and holding himself or herself out as married to that person. ${ }^{7}$

$\dagger$ Professor of Law, Boalt Hall School of Law, University of California at Berkeley. B.A. 1956, Southern Methodist University; J.D. 1959, University of Chicago. The author was a member of the California Governor's Commission on the Family, Co-Reporter of the Uniform Marriage and Divorce Act, and a Co-Investigator on the Califorma Divorce Law Research Project (Dr. Lenore Weitzman, Principal Investigator). I am grateful to ny research assistant, Barbara Flagg, for her help.

1. Family Law Act of 1969, ch. 1608, 1969 Cal. Stat. 3312, 3314-51 (codified as amended at Cal. Clv. Code $\$ \S 4000-5100$ (West 1983 \& Supp. 1987)).

2. CAL. CIv. CODE $\S 4506$ (West 1970) (listing two grounds for dissolution of marriage: (1) "irreconcilable differences, which have caused the irremediable breakdown of the narriage" and (2) "incurable insanity") (current version at CAL. Crv. CODE $§ 4506$ (West 1983)); id. $\$ 4507$ (defining "irreconcilable differences") (current version at CAL. CIV. CODE $\S 4507$ (West 1983)); id. $\S 4510$ (defining "incurable insanity") (current version at CAL. Civ. CODE $\S 4510$ (West 1983)).

3. CAL. CIV. CODE $\$ 4801$ (West 1970) (circumstances to be considered when awarding spousal support) (current version at CAL. Crv. CoDE $§ 4801$ (West 1983 \& Supp. 1987)).

4. Cal. CIv. CoDE $\$ 4800$ (West 1970) (division of community and quasi-community property) (current version at CAL. CIv. CODE $\$ 4800$ (West 1983 \& Supp. 1987)).

5. CaL. Crv. CoDE $\S 4508$ (West 1970), amended by Act of Apr. 18, 1975, ch. 35, $\S 1,1975$ Cal. Stat. 59 (deleting exception relating to irreconcilable differences) (current version at CAL. Crv. CODE. $\S 4508$ (West 1983)). 1983)).

6. CAL. CIv. Code $\S 4509$ (West 1970) (current version at CAL. Crv. Code $\S 4509$ (West

7. Family Law Act of 1969, ch. 1608, 1969 Cal. Stat. 3312, 3334 (codified at CAL. Crv. CoDE $\S 4801$ (c) (West 1970)) (current version at CAL. Civ. CODE $\S 4801.5$ (West 1983 \& Supp)). 
The California Family Law Act of $1970,{ }^{8}$ which embodied the nofault divorce law, was the concrete result of seven years of work by legislative committees, citizens' advisory groups, a governor's commission, and family law committees of state and local bar associations. ${ }^{9}$ In a larger sense, the Act represented the first significant breakthrough im an historic social and moral impasse over divorce. That impasse was characterized by an uneasy and largely unspoken compromise between legal theory, which preserved the ideal of marriage as imdissoluble except for specific acts of marital misconduct, and courtroom practice, which granted divorces based simply on an agreement between the spouses. ${ }^{10}$

California, as the first American state to choose a marital dissolution standard based on a showing of factual marriage breakdown rather than mutual consent, identified a way out of the impasse that was influential in the reform effort $m$ other states. Following Cahfornia's lead, the National Conference of Commissioners on Uniforni State Laws adopted a dissolution standard for the Uniform Marriage and Divorce Act based on the irretrievable breakdown of the marriage. ${ }^{11}$ Today, all American states provide, in one form or another, a statutory basis for inarital dissolution that does not require a showing of fault. ${ }^{12}$

The California law is also the first no-fault divorce law to be the subject of an empirical study. Dr. Lenore Weitzman ${ }^{13}$ has found that the California law succeeded in removing fault from all aspects of the dissolution process, but that its achievement has had an unanticipated cost:

8. See supra note 1 .

9. See generally Kay, Equality and Difference: A Perspective on No-Fault Divorce and Its Aftermath, 56 U. CIN. L. REv. (forthcoming July 1987); Krom, California's Divorce Law Reform: An Historical Analysis, 1 PAC. L.J. 156 (1970).

10. See generally M. Rheinstein, MaRriage Stability, Divorce, AND the LAw 367-82 (1972) (discussing the California law); Friedman, Rights of Passage: Divorce Law in Historical Perspective, 63 OR. L. REv. 649 (1984).

11. UNIF. MARRIAGE AND DivorCe Act § 305, 9A U.L.A. 91, 132-33 (1979).

12. See Kay, supra note 9 at nn. 19-20, 22 (identifying three groups of states: those with "pure" no-fault divorce laws; those with mixed fault and modern no-fault laws; and those with mixed fault and traditional no-fault laws).

13. L. Weitzman, The Divorce Revolution: The Unexpected Social and Economic CONSEqUENCES FOR WOMEN AND CHILDREN IN AMERICA 20-32, 357-62 (1985). Dr. Weitzman's research had four components. First, she and her collaborators examined a sample of court records in 500 cases deeided in San Francisco and 500 decided in Los Angeles in 1968, two years before the Family Law Act became effective, and an equal number of cases from the same counties in 1972, two years after the effective date of the new law. Second, she conducted imterviews with 44 judges and commissioners who were assigned to the domestic relations calendar in 1974 and 1975 in both counties. Third, she mterviewed 169 matrimonial lawyers during the same years in both counties. Finally, she held in-depth structured interviews in 1978 with 228 recently divorced men and women in Los Angeles county. Id. at 403-411. Weitzman's research has been criticized for her use of quantitative data, her generalization of her findings from California to the nation, and her conclusion that the ill-effects of divorce she indentifies were the result of the no-fault divorce reforms. Jacobs, Faulting No-Fault, 1986 AM. B. FOUND. RES. J. 767 (forthcoming) (symposium issue on Weitzman's Divorce Revolution). 
the financial impoverishment of divorced women and the children who remain predominantly im their custody. She concludes that, despite its promise of equality for woinen and men, the no-fault divorce law disadvantaged women by failing to take account of their unequal situation during marriage. ${ }^{14}$

In this Article, I propose to appraise Califorina's no-fault divorce law in light of Weitzman's findings, and in light of some of the social and legal changes that have occurred since its enactment. First, I will describe the conventional framework of marriage and family regulation that was in place when the Family Law Act became effective in 1970. Next, I will review briefly the considerations that led to the elimination of fault as an issue in divorce proceedings. Third, I will show that the achievernent of legal equality between women and men was not a central goal of the divorce reform effort in California. Rather, the concept of equality energed after the enactment of the no-fault law as an influential factor in obtaining additional reform in related areas of family law. Then, I will describe the legal regulation of family life in California as it exists today, showing that it provides a supportive context for substantive, rather than fornial, equality. Finally, I will suggest further changes in the no-fault divorce law that may lessen some of the adverse consequences Weitzman has identified, and may facilitate still further the achievement of substantive equality at divorce.

I

\section{Legal Regulation of MarRiage, Divorce, AND the FAMILY IN 1970}

In 1970, California law recognized the husband as the head of the family. ${ }^{15} \mathrm{He}$ had the sole power to manage the community property, ${ }^{16}$ except for the wife's earnings. ${ }^{17}$ A married woman who did not work outside the home and who had no separate property could not obtain

14. L. WEITZMAN, supra note 13, at 365-66.

15. Cal. Clv. Code $\S 5101$ (West 1970) ("The husband is the head of the family. He may chose [sic] any reasonable place or mode of living, and the wife must conform thereto."), repealed by Act of Oct. 1, 1973, ch. 987, § 2, 1973 Cal. Stat. 1898.

16. CAL. CIV. CODE $\S 5105$ (West 1970) (identifying husband as manager of the community property); id. $\S 5125$ (management of community personal property); id. $\S 5127$ (management of community real property). These sections were substantially revised by the Act of Oct. 1, 1973, ch. 987, $\S 4,14,15,1973$ Cal. Stat. 1898, 1901-02 (eff. Jan. 1, 1975); see current versions at CAL. Civ. CODE $\$ \S 5105,5125$, and 5127 (West 1983 \& Supp. 1987). See also infra text accompanying notes 93-95. The Act of Sept. 23, 1986, ch. 1091, 1986 Cal. Legis. Serv. 565 (West) amended $\S 5125$ and added $\S 5125.1$; see infra text accompanying note 111 .

17. CAL. Civ. CoDE $\S 5124$ (West 1970), repealed by Act of Oct. 1, 1973, ch. $987, \S 13,1973$ Cal. Stat. 1901. (Section 5124 was a reenactment, without significant change, of former Act of June 16, 1951, ch. 1102, §1, 1951 Cal. Stat. 2860-61, codified at former CAL. Crv. CoDE $\$ 171(c)$ ). 
credit in her own name without her husband's consent, ${ }^{18}$ even though she owned an undivided one-half interest in the community property. ${ }^{19} \mathrm{~A}$ wife had no clear legal renuedies available to her during the marriage to prevent her husband's mismanageinent of their property, ${ }^{20}$ and no clear right even to know the extent or location of the community assets. ${ }^{21}$ While California law did not require a woman to take her husband's surname on marriage, ${ }^{22}$ she customarily did so, and their children took the father's name. ${ }^{23}$ Although each spouse had responsibility for the support of the other spouse and their children, ${ }^{24}$ the primary legal burden of support during the ongoing marriage fell on the husband, with the wife cast in the role of his assistant. ${ }^{25}$

Upon dissolution of the marriage, the new Family Law Act permitted the couple to divide their community property as they saw fit. ${ }^{26}$ If they were unable to agree, however, the Act inandated an equal division of the marital property, subject to two exceptions: the existence of economic circumstances justifying the award of an asset to one party under conditions that would produce a "substantially equal division"; and the existence of financial misconduct resulting in one party's deliberate nisappropriation of assets. ${ }^{27}$ Either spouse might obtain support from the otler; a court awarding spousal support was to consider the circumstances of the parties, including the lengtl of the inarriage, and the supported spouse's capacity for self-support in hight of the interests of the children in that spouse's custody. ${ }^{28}$ The Act accorded parents priority

\footnotetext{
18. Comment, California's New Community Property Law-Its Effect on Interspousal Mismanagement Litigation, 5 PAC. L.J. 723, 724 (1974).
}

19. Cal. Crv. Code $\S 5105$ (West 1970). Section 5105 was amended by Act of Oct. 1, 1973, ch. $987, \S 4,1973 \mathrm{Cal}$. Stat. 1898 to delete the phrase "under the management and control of the husband as is provided im Sectious 5125 and 5127." See current version at CAL. CIV. CoDe $\S 5105$ (West 1983).

20. See Grant, How Much of a Partnership is Marriage? Community Property Rights Under the California Family Law Act of 1969, 23 Hastings L.J. 249, 251-54 (1971).

21. See Bruch, Management Powers and Duties Under California's Community Property Laws: Recommendations for Reform, 34 HASTINGS L.J. 227, 234-36 (1982).

22. See Hughes, And Then There Were Two, 23 HASTINGs L.J. 233, 236-39 (1971).

23. Id. at 243-45.

24. CAL. CIv. CoDE $\S 196$ (West 1970) (support of child); id. $\S 242$ (man's duty to support his wife and child); id. $\S 243$ (woman's duty to support her child and husband); id. $\S 246$ (relevant circumstances for determining support); id. $\S 5100$ (mutual support obligations of spouses). Sections 242, 243, and 246 were part of the Umiform Civil Liability for Support Act of 1955, 1955 Cal. Stat. 1451; see current versions in CAL. Crv. Code (West 1983).

25. CAL. CIV. CoDE $\S 196$ (West 1970) (providing in part, that "[i]f the support and education which the father of a legitimate child is able to give are inadequate, the mother must assist him to the extent of her ability") (repealed 1980).

26. Cal. CIv. CoDE $\S \S 4802,4811$ (West 1970) (current versions at CAL. Crv. CoDE $\S \S 4802$, 4811 (West 1983 \& Supp. 1987)).

27. CaL. CIv. Code $\S 4800(1)$-(2) (West 1970) (current version at CAL. Crv. CoDe $\S 4800$ (West 1983 \& Supp. 1987).

28. CAL. CIV. CoDe $\S 4801$ (West 1970). Several amendments to $\S 4801$ expanded the list of 
over other persons in obtaining custody of their children, ${ }^{29}$ and it continued the earhier statutory preference for inothers as custodians of young children. ${ }^{30}$ The court might order either or both parents to provide "any amount necessary" for the support of their children, ${ }^{31}$ but no statutory standards guided the court in setting that amount. ${ }^{32}$

In 1970, inarriage was limited to heterosexual couples. ${ }^{33}$ Case law characterized couples knowingly hiving together without marriage as occupying a "meretricious" relationship," and limited their property rights to those based on contract ${ }^{35}$ or arising from the contribution of financial assets rather than the provision of services. ${ }^{36}$ Children born to an unmarried cohabiting couple were illegitimate. ${ }^{37}$ Illegitimate children could be legitimated by the marriage of their natural parents, ${ }^{38}$ or by the conduct of the father im receiving the child into his home, with the consent of his wife if he was inarried, and treating the child as legitimate. ${ }^{39}$ If the child was not legitimated, however, the mother exercised sole

circumstances to be taken into account when setting a spousal support award; see Act of May 5 , 1976, ch. 130, § 5, 1976 Cal. Stat. 209-10; Act of Sept. 21, 1979, ch. 912, § 1, 1979 Cal. Stat. 314041 ; and Act of Mar. 1, 1984, ch. 19, § 1, 1984 Cal. Legis. Serv. 105-106 (West). The current version of the statute is at CAL. CIV. CODE $\S 4801$ (West 1983 \& Supp. 1987).

29. CAL. CIV. CODE $\S 4600$ (West 1970) (giving highest priority to parents and requiring that, before custody can be awarded to a nonparent over the parents' objection, the court must find "that an award of custody to a parent would be detrimental to the child, and the award to a nonparent is required to serve the best interests of the child"). Despite the subsequent adoption of a joint custody provision in 1980, revised in 1984, see infra text accompanying note 138, the quoted language remains in the statute. CAL. Crv. CODE $\$ 4600$ (West Supp. 1987).

30. CAL. Civ. CODE $\S 4600$ (West 1970). The maternal presumption was repealed by Act of Aug. 12, 1972, ch. 1007, $\S 1,1972$ Cal. Stat. 1854-55; see current version at CAL. CIV. CODE $\S 4600$ (West 1983 \& Snpp. 1987).

31. Cal. Civ. Code $\S 4700$ (West 1970) (current version at Cal. Civ. Code $\S 4700$ (West 1983 \& Supp. 1987)).

32. The Agnos Child Support Standards Act of 1984, ch. 1605, 1984 Cal. Legis. Serv. 557-58 (West) (codified at CAL. Crv. CoDE $\$ \S 4720-4732$, as amended by Act of July 30, 1985, ch. 379, § 4, 1985 Cal. Legis. Serv. 394 (West)), provides a mandatory minimnm child support award.

33. No California case has tested this proposition. However, courts elsewhere have held that a state inay constitutionally restrict marriage to heterosexual couples. See, e.g., Baker v. Nelson, 291 Minn. 310, 191 N.W.2d 185 (1971), appeal dismissed, 409 U.S. 810 (1972).

34. See, e.g., Gjurich v. Fieg, $164 \mathrm{Cal} .429,432,129$ Pac. 464, 466 (1913) (denying recovery to a man for services he performed as a gardener and carpenter on property owned and operated as a saloon and bar by a woman with whoin he lived in noumarital cohabitation).

35. Trutalli v. Meraviglia, 215 Cal. 698, 700-02, 12 P.2d 430, 431 (1932).

36. Keene v. Keene, 57 Cal. 2d 657, 668, 371 P.2d 329, 335-36, 21 Cal. Rptr. 593, 599-600 (1962) (no property rights created by contribution of services in operating a ranch); Vallera v. Vallera, 21 Cal. 2d 681, 684-85, 134 P.2d 761, 762-63 (1943) (no property rights created by contribution of services as a homeinaker).

37. CAL. EvID. CoDE $\S \S 621$ (West 1968) (conclusive presumption of legitimaey); id. $\$ 661$ (rebuttable presuinption of legitimacy), repealed by Act of Oct. 1, 1975, ch. 1244, \$14, 1975 Cal. Stat. 3202; current version at CAL. CIV. CODE § 7004(a)(1) (West 1983).

38. Cal. Civ. Code $\S 215$ (West 1974), repealed by Act of Oct. 1, 1975, ch. 1244, $\$ 5,1975$ Cal. Stat. 3195.

39. Cal. Civ. CoDE $\S 230$ (West 1974), repealed by Act of Oct. 1, 1975, ch. 1244, § 8, 1975 Cal. Stat. 3196. 
parental authority over the child's upbringing. ${ }^{40}$ If identified in a paternity action, the father could be held hable for the child's support, ${ }^{41}$ but he had no parental right to custody and he could not prevent an adoption. ${ }^{42}$ An illegitimate child had no right to be received nito the father's honie $^{43}$ and normally could inherit only through the n1other. ${ }^{44}$

Sodoniy laws ${ }^{45}$ may have inhibited nuany honısexual couples fron living together in open cohabitation for fear of revealing their sexual orientation. In divorces of married couples in which one spouse was hon1osexual, that spouse frequently experienced great difficulty in maintaining contact with the children after divorce. Althougli Califorma courts did not hold gay parents unfit as custodians merely because of their sexual orientation, ${ }^{46}$ little more was required to sustain an award of custody to the other parent based on the best interests of the child. ${ }^{47}$ Homosexual partners who had not produced children in heterosexual relationships found it difficult to experience parental relationships. Single parent adoption was rare; ${ }^{48}$ co-adoption by cohabiting persons of the sanie sex

40. The mother of an illegitimate child had the sole right to the child's custody, services, and earnings, CAL. CIV. CoDE $\$ 200$ (West 1970): as the parent entitled to custody, she established the child's legal residence, id. $\S 213$, she was responsible for the child's support, id. $\S 196 \mathrm{a}$, and only her consent was necessary for the child's adoption, $i d$. $\S 224$. The mother and her illegitimate child had reciprocal rights to inherit property from each other, CAL. Prob. CODE $\$ \S 255,256$ (West 1970). Civil Code $\S \S 196 a, 200,224$, and Probate Code $\S \S 255$ and 256 were modified or repealed when California adopted the Uniform Parentage Act in 1975. See Uniform Parentage Act of 1975, ch. 1244, part 7, 1975 Cal. Stat. 3196-3204 (codified as amended at CAL. CIv. CoDE $§ \S 7000-7018$ (West 1983 \& Supp. 1987)).

41. CAL. CIV. CODE $\S 196 a$ (West 1970). This section was amended by the Act of Oct. 1 , 1975 , ch. $1244, \S 2.5,1975$ Cal. Stat. 3195 , to eliminate any reference to illegitimacy.

42. See supra note 40.

43. Louden v. Olpm, 118 Cal. App. 3d 565, 568, 173 Cal. Rptr. 447, 449, cert. denied, 454 U.S. 1055 (1981). After Louden was decided, the Legislature enacted the Act of Sept. 30, 1984, ch. 1616, $\S \S 1,2,1984$ Cal. Legis. Serv. 656-57 (codified at CAL. Penal CoDE § 270.5 (West Supp. 1987)) (making a parent's refusal, without lawful excuse, to accept his or her minor child into the parent's home, or to provide alternative shelter, a misdemeanor).

44. See supra note 40. Under CAL. Prob. CODE $\$ 256$ (West 1970), an illegitimate child could inherit from a man who acknowledged himself, in writing, to be the child's father.

45. Act of May 13, 1975, ch. 71, § 7, 10, 1975 Cal. Stat. 133-34 (amending Cal. Penal CodE $\S \S 286,288 \mathrm{a})$.

46. Nadler v. Superior Court, 255 Cal. App. 2d 523, 63 Cal. Rptr. 352 (1967) (mother's homosexuality insufficient, as a matter of law, to support an order denying her custody).

47. On remand in Nadler, supra note 46 , the trial court again awarded custody to the heterosexual father, this time basing its order on the testimony of a psychiatrist that the mother would have greater difficulty than the father in encouraging their children to seek heterosexual relationships and that she would be impaired in teaching them a "traditional concept of morality." Nadler v. Nadler, No. 177331 (Sacramento County, Cal. Super. Ct. Nov. 15, 1967). See D. MARTIN \& P. LYON, LESBIAN/WOMAN 137-39 (1972).

48. CAL. Crv. CoDE $\S 221$ (West 1982) has, since its enactment in 1872, permitted the adoption of "any" minor child by "any" adult. The practices of adoption agencies, however, prefer married couples to single persons or to unmarried couples as potential adoptive parents. See CHILD Welfare League of America, STANDARdS for Adoption Service: Revised $\$ 5.19$ (rev, ed. 1973). 
was unknown; ${ }^{49}$ and artificial insemination was just beginning to become easily available. ${ }^{50}$

This brief summary of California laws affecting nnarriage and the family in 1970 discloses a traditional regulatory mode. Apart froin its new no-fault divorce law and its minority status as one of eight American states that follow a civil law approach to marital property, ${ }^{51}$ California's laws regulating family life were not remarkable when compared with those existing in other states. A significant factor that has distinguished California's family law development from that of other states simce 1970 is the willingness of the legislature and the courts to extend the no-fault philosophy underlying the Family Law Act into other areas of family law. This attitude has fostered an unusual freedon that allows Californians to experiment with a variety of family fornıs and functions uninhibited by any officially imposed view of appropriate family life. Before turning to an examination of the ways in which California law has developed since 1970, it is useful to review briefly the considerations that led to the shift froin a fault to a no-fault philosophy in divorce.

\section{II}

\section{The Elimination of Fault in Divorce}

In the years immediately preceding the enactment of the Family Law Act, an enornious gulf existed between the divorce law on the statute books, which declared inarriage indissoluble except for inarital fault, and the law in practice, which tolerated divorce by mutual consent. ${ }^{52}$ In 1966, approximately ninety-five percent of all imitial coinplaints for divorce or separation in California were filed on the ground of extreme cruelty. ${ }^{53}$ Nevertheless, two factors characteristic of nearly all divorces in California during this period indicated that they were the product of a

49. Co-adoption of this kind is rare even today. See, e.g., Comment, Second Parent Adoption for Lesbian-Parented Families: Legal Recognition of the Other Mother, 19 U.C. DAv1s L. REv. 729, 732-33 (1986).

50. California was one of the first states to permit married heterosexual couples to produce


289, 437 P.2d 495, 501, 66 Cal. Rptr. 7, 13 (1968); CAL. Crv. CODE § 216 (West 1970). Homosexual couples, and unmarried heterosexual women, now use this technique to bear children and raise them in nonconventional family settings. See generally, O'Rourke, Family Law in a Brave New World: Private Ordering of Parental Rights and Responsibilities for Donor Insemination, 1 BERKELEY WOMEN'S L.J. 140 (1985).

51. See Loewy, The Spanish Community of Acquests and Gains and Its Adoption and Modification by the State of Califormia, 1 CAL1F. L. REV. 32 (1912).

52. See Friedman, supra note 10, at 659-61.

53. Bureau of Vital Statistics, Cal. Dep't. of Pub. Health, Divorce in California: Initial Complaints for Divorce, ANNUlment and SePaRAte Maintenance 1966, at 14 (1967). 
mutual agreement: they were uncontested, ${ }^{54}$ and they were granted on perfunctory testimony of marital fault. ${ }^{55}$

Two eartier California cases had created the conditions that made divorce by mutual consent possible. In Hill v. Hill, ${ }^{56}$ Chief Justice Gibson had upheld a separation agreement even though it was expressly conditioned upon the parties' subsequent divorce. Hill thus made it possible for spouses to negotiate opeuly the financial terms upon which one of them would be allowed to obtain a divorce. While that decision represented a welcome elimination of the hypocrisy that the law earlier had required of spouses, it also strengthened the hand of a party who did not wish to be divorced. The law allowed that party to demand a high price for cooperation in the procedure without fear that the agreement could be attacked later as violative of public pohicy. In De Burgh v. De Burgh, ${ }^{57}$ Justice Traynor had allowed divorces to be granted to both parties if both were equally at fault. The decision eliminated one of the chief weapons available to the spouse who wanted to prevent the divorce by removing that spouse's own threatened cause of action for divorce as a legal defense. ${ }^{58}$ After De Burgh, the price of a spouse's refusal to cooperate in obtaining a divorce became lower. De Burgh did not eliminate blackmail from divorce negotiations, but it took a significant step in that direction and pointed the way for more sweeping reforms.

During the period between the De Burgh decision in 1952 and the no-fault proposal of the Governor's Commission on the Family in 1966 (which drew its standard from Traynor's language in that case), ${ }^{59}$ criticism of fault as the theoretical basis for divorce became widespread. The Archbishop's Group in England provided a particularly thoughtful critique $^{60}$ that was well received in California. The Governor's Commission noted that its proposal to eliminate fault was influenced by the Group's analysis. ${ }^{61}$ The Commission's proposal, in turn, played a significant role in producing the 1970 no-fault law. ${ }^{62}$

54. REPORT OF THE GOVERNOR'S COMM1SSION ON THE FAMILY 30-31 (1966) (estimating that 94\% of divorce hearings in California were uncontested) (hereinafter cited as REPORT).

55. Id. at $119 \mathrm{n} .23$ (giving a "typical example of the melancholy and perfunctory litany of uncontested divorce").

56. 23 Cal. 2d 82, 93, 142 P.2d 417, 422 (1943).

57. $39 \mathrm{Cal} .2 \mathrm{~d} 858,873-74,250$ P.2d 598, 607 (1952).

58. See Armstrong, Family Law: Order Out of Chaos, 53 CALIF. L. REv. 121, 124 (1965) ("It would be hard to overestinate how inuch [De Burgh] did to restore integrity to the very process of law in divorce proceedings.").

59. See REPORT, supra note 54, at 91 (identifying Traynor's language in De Burgh as the basis of the standard for no-fault divorce contained in $\S 028$ of the proposed Family Court Act).

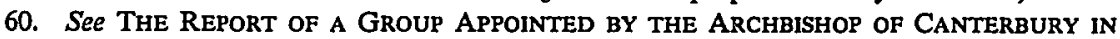
January 1964, Putting Asunder: A Divorce LaW for Contemporary SOCIETy 25.32 (1966).

61. REPORT, supra note 54, at 26-32; see also Krom, supra note 9, at 168.

62. See Krom, supra note 9, at 170. 
The motivations of those who participated in the California divorce reform effort were far froin uniform, but inost of them shared the view that divorce based on fault no longer served the public interest. They undertook to design and impleinent a divorce law that would take account of the reahties of married life, the economic needs of divorced dependent spouses, and the best interests of children. As it turned out, however, the approach to inarriage termination adopted in the California Family Law Act in 1970 was quite different froin, and more radical than, the 1966 recommendations of the Governor's Commission on the Family. ${ }^{63}$ The elimination of fault, the one goal common to all reform proposals, was the only recommendation to survive the legislative process relatively intact. The Commission's proposal for a Family Court with speciahist judges and a staff of tramed counselors was sacrificed. ${ }^{64}$ Moreover, the Act did not reflect the Commission's recognition ${ }^{65}$ that some cases might require an unequal division of community assets in order to protect the dependent spouse and children. Instead, the Act imposed an equal division of inarital assets in virtually all cases, with only two exceptions. ${ }^{66}$ In the seventeen years following the Act's passage, the no-fault philosophy underlying the divorce law itself became the cutting edge of other changes that have transformed California's marriage and family law.

\section{III}

\section{The INTRODUCtion OF THE THEME OF LEgAL EQUALITY}

The California reform effort that produced the Family Law Act ended in 1969. One of its major goals, and its 1nost endurmg achievement, was to free the administration of justice in divorce cases froin the hypocrisy and perjury that had resulted from the use of marital fault as a controlling consideration in divorce proceedings. ${ }^{67}$ Less well articulated,

63. See Kay, supra note 9, text accoinpanying notes 195-213 (noting the differences between the Commission's proposed Family Court Act and the Family Law Act); see also Kroin, supra note 9, at 174-77.

64. See Kroin, supra note 9, at 173.

65. See REPORT, supra note 54, at 45 (noting that although "an equal disposition of the community assets is desirable, leaving the inaintenance needs to be inet by appropriate awards of alimony and child support[]. ... [w] realize ... that an absolutely equal division is inpractical, if not impossible, in inany cases," and observing that "an equal division may fail to give sufficient protection to the wife and children, even though their needs would normally be provided for through alimony and support awards").

66. See supra text accompanying note 27.

67. Professor Grace Blumberg discounts the significance of the elinination of fault in divorce, arguing that the legal profession is the primary beneficiary of the reform because "[l]awyers and judges are no longer required to systematically comproinise professional idcals in the routine management of divorce cases." Blumberg, New Models of Marriage and Divorce, in Contemporary Marriage 349, 352 (K. Davis ed. 1985) (citation omitted). Even if one agrees with this statement, however, it does not follow that the no-fault reform was insignificant. Those 
however, were the economic circumstances to be considered in the absence of fault to decide the cases. The Report of the Governor's Commission on the Family had attempted to substitute a nonadversary procedure administered in a Family Court that would encourage the spouses to resolve their differences with the help of a trained staff of counselors. ${ }^{68}$ The Family Law Act rejected that inodel, although it encouraged the voluntary establishment of local Courts of Conciliation similar to those in use in Los Angeles County. ${ }^{69}$ After the Family Law Act was passed, but before it becaine effective, the Assembly Committee on Judiciary issued a Report ${ }^{70}$ declaring its legislative intent in proposing the new law. As a guiding interpretative principle of the Act's financial provisions, Assemblyman James A. Hayes, Chair of the Cominttee and author of its Report, offered a new consideration: the "approaching equality"71 between women and inen.

The achievement of equality between women and men had not been among the stated goals of any of the participants in California's divorce reform effort. ${ }^{72}$ In 1969, when the proposed Fainily Law Act was before the legislature, the Commission on the Status of Women supported the removal of fault froin divorce as a desirable elimination of hypocrisy in the legal system, ${ }^{73}$ not because it promised equality between men and women.

Certain provisions of the new law, however, treated divorcing spouses alike, without regard to sex, and were therefore consistent with

who have forgotten the type of evidence required to prove fault in contested cases would do well to look at soine inodern examples in states that retain fault as a ground for divorce. See, e.g., Barr v. Barr, 58 Md. App. 569, 473 A.2d 1300 (affirming an order granting wife a divorce on the grounds of her husband's adultery and constructive desertion), cert. denied, $300 \mathrm{Md} .794$ (1984).

68. See REPORT, supra note 54, at 17-25. See generally Kay, A Family Court: The Californla Proposal, 56 CALIF. L. REv. 1205 (1968).

69. See Kroin, supra note 9, at 174-75, 178.

70. California Assembly Committee on Judiciary, Report on A.B. No. 530 AND S.B. No. 252 (The Family LAw ACT), 4 Cal. Assembly Dally J. 8053 (1969).

71. Id. at 8062 . The full passage reads:

When our divorce law was originally drawn, wounan's role in society was almost totally that of mother and homemaker. She could not even vote. Today, increasing numbers of married women are einployed, even in the professions. In addition, they have long been accorded full civil rights. Their approaching equality with the male should be reflected in the law governing marriage dissolution and in the decisions of courts with respect to matters incident to dissolution.

Id. Mr. Hayes subsequently cited this passage in a brief filed in support of his motion to terminate a court order requirmg him to support his former wife. See R. EISLER, Dissolution: No-FAult DivorCe, MARRIAGE, AND THE FUTURE OF WOMEN 28 (1977).

72. In some common law states that began their examimation of divorce laws after 1970, reformers identified equality between women and unen as one of their goals. See Fineman, Implementing Equality: Ideology, Contradiction and Social Change. A Study of Rhetoric and Results in the Regulation of the Consequences of Divorce, 1983 WIS. L. REV. 789, 853-67.

73. Report of the Advisory COMM'N ON THE Status of WOMEN, California Women 1969 , at $79-80$. 
an ideal of formal equality between women and men. Chief among these provisions was the requirement that community and quasi-community property be divided equally. Indeed, an authoritative interpretation of the new law, prepared by four judges and intended as a guide for lawyers, concluded that the equal division provision was a more significant change from prior law than the elimination of fault. ${ }^{74}$ The authors suggested that "[t]he parties now will be considered partners whose interests in their community and quasi-community property are not subject to the discretion of the trial judge on either moral or economic grounds."75 Judges retained their traditional discretion only in setting the spousal and child support awards.

There is some evidence that California divorce court judges interpreted the Assembly Committee Report as a mandate to eliminate longterm spousal support for dependent wives. ${ }^{76}$ Others, however, used the Report's observation about women's "approaching equality" with men as a basis for pressing for legislative reform in related areas in order to make that prediction a reality. They were interested, in particular, in reform of the community property laws. In 1967, the Califormia Commission on the Status of Women had called for a "inajor legislative study" of the community property laws. ${ }^{77}$ The study would propose legislation to "equalize both the rights and duties of the husband and wife in the control, management and disposition of their commumity property to create a true economic partnership between the spouses."78 In 1971, Judge Isabella Grant, then a specialist in matrimomial law, made a similar recommendation, citing Assemblyman Hayes's observation. ${ }^{79}$ She urged that

74. M. Freeman, W. Hogoboom, W. MACFADDEN \& L. OLSON, Attorney's Guide to FAMILy LAW ACt PRACTICE 156 (1970) [hereinafter cited as ATTORNEY's GuIDE]. See also Levin, Virtue Does Not Have Its Reward for Women in California, 61 WOMEN LAw. J. 55,57 (1975) (concluding after several years' experience with the equal division provision that, because of the different functions performed by husbands and wives during the marriage, "[u]nfortunately, however noble its aims, the no-fault equal division of community property provision of our state law is, sadly, some 20 to 30 years ahead of its time.") (emphasis omitted).

75. Id. at 156 .

76. Two years after the Family Law Act became effective, an appellate court found it necessary to correct this mistaken interpretation. See In re Marriage of Rosan, 24 Cal. App. 3d 885, 897, 101 Cal. Rptr. 295, 304 (1972) (reversing spousal support order as inadequate in a case in which wife had not worked outside the home during the 17-year marriage, and observing that "[w]e find nothing in the Family Law Act ... indicating any legislative intent that a wife of a marriage of longstanding whose attentions have been devoted during the marriage to wifely and parental duties and whose earning capacity has therefore not been developed should be, at a time when the husband is reaching his peak of earning capacity, relegated to a standard of living substantially below that enjoyed by the parties during the marriage or to subsistence froin public welfare"); see also L. WEITZMAN, supra note 13 , at $184-94$.

77. Report of the Advisory Comm'N on the Status of Women, California Women 1967 , at 31 .

78. Id.

79. Grant, supra note 20 , at 250 . 
community property law reform was necessary to carry out the philosophy implicit in the no-fault divorce law: that inarriage was an economic partnership. ${ }^{80}$ In response to these recommendations, the legislature held a series of hearings devoted to the subject of community property. ${ }^{81}$

By the time these hearings commenced in September of 1972, public attention in California had already focused on wonren's efforts to gain legal equality with nien. In 1970, the legislature had added "sex" as a protected category to the Fair Einployinent Practices Act, which prohibited discrimination in enployment. ${ }^{82}$ In 1971 , the California Suprente Court had declared classifications based on sex to be suspect and subject to strict scrutiny under the equal protection clause of the state constitution. ${ }^{83}$ Early in 1972, Congress had proposed an Equal Rights Amendnient to the U.S. Constitution. ${ }^{84} \mathrm{~A}$ drive to ratify the anrendnent was underway in California at the time of the hearmgs; in Nove1nber of 1972, tlie drive succeeded. ${ }^{85}$

In light of these circunistances, it is not surprising that the proponents of equal managenient powers for wives based their arguments primarily on the principle of equality. ${ }^{86}$ Sone witnesses at the legislative hearings ${ }^{87}$ also insisted, however, that the no-fault divorce law and its mandate for equal property division ineant that wives could not adequately protect themselves against a husband's dissipation or secreting of the community assets unless they had an equal right to control the property. Other witnesses ${ }^{88}$ criticized a 1971 statute, introduced by Assemblyinan Hayes, which was designed to equalize the treatnent of husbands after separation, but had a detrimental impact on wives. The measure provided that the earnings of husbands, like those of wives, would be their separate property after separation. ${ }^{89}$ Since the husband continued to inanage the community property after separation, lowever, the legisla-

80. Id. at 256-57.

81. Cal. JoInt InTERIM COMm. ON Judiciary, Hearings on Community Property (Sept. 25-26, 1972; Oct. 10, 1972; Oct. 20, 1972) [hereinafter HEARINGS on CoMmuNITY Property].

82. Act of Sept. 19, 1970, ch. 1508, § 2, $1970 \mathrm{Cal}$. Stat. 2993, 2994 (codified at CAL. LAB. CODE $\S 1412$ (West 1971), repealed and re-enacted by Act of Sept. 19, 1980, ch. 992, § 4, 1980 Cal. Stat. 3138, 3140 (codified at CAL. Gov'T CoDE $\S 12921$ (West 1980)).

83. Sail'er Inn, Inc. v. Kirby, 5 Cal. 3d 1, 17-20, 485 P.2d 529, 539-41, 95 Cal. Rptr. 329, 33941 (1971) (invalidating state law prohibiting woinen froin working as bartenders).

84. H.R.J. Res. 208, 92 d Cong., 2d Sess., 118 CONG. REC. 9598 (1972).

85. S.J. Res. 20, 1972 Reg. Sess., 4 CAl. Assembly Daily J. 7596 (Nov. 13, 1972).

86. Hearings on Community Property, supra note 81, at 2 (testimony of Ruth Church Gupta); id. at 69-70 (testimony of Marilyn Patel).

87. Id. at 80-81 (testimony of Mildren W. Levin).

88. Id. at 41 (testimony of Isabella H. Grant); id. at $102-03$ (testimony of Zaide Kirtley); id. at 168-69 (testimony of Amy White Fixler).

89. Act of Dec. 10, 1971, ch. 1699, 1971 Cal. Stat. 3639 (amending CAL. Crv. CoDE $\S \S 5118$, 5119 (West 1983)). 
tion enabled him to use any community funds accumulated prior to the separation to support himself, his wife, and their children while keeping his earnings acquired after separation in reserve for his own purposes. ${ }^{90}$ If a lengthy period of separation preceded the dissolution, there might be very hittle community property left to divide. Several witnesses urged that in order to prevent unfairness to wives, the measure should be repealed and the former law reinstated to define the husband's earnings as commuinty property until the entry of a decree of separation or dissolution. ${ }^{91}$

Three legislative measures grew out of the community property hearings. One provision, effective in 1974, prohibited the denial of credit to a married woman whose property and income were such that a similarly situated man would be able to obtain credit.92 A more sweeping provision, effective on January 1, 1975, extended to wives the same power to manage community property that their husbands had enjoyed..$^{93}$ An exception to this provision granted a spouse engaged in a business which is community personal property the sole power to inanage and control that business. ${ }^{94}$ Both spouses were directed to inanage the property in "good faith."95

The third measure, effective on July 1, 1975, changed the probate laws to permit a widow to assume ownership of the community estate following her husband's death without having the entire estate administered in probate. ${ }^{96}$ This provision extended to widows the same powers that widowers had previously held following the death of their wives. ${ }^{97}$

90. But see In re Marriage of Epstein, 24 Cal. 3d 76, 89, 592 P.2d 1165, 1173, 154 Cal. Rptr. 413,421 (1979) (husband who used his preseparation earnings that were community property to pay income taxes on his postseparation earnings that were his separate property required to reimburse the community estate).

91. See, e.g., Hearings ON COMMUNITY Property, supra note 81, at 66-67 (testimony of Sydney Traxler).

92. Act of Oct. 1, 1973, ch. 999, § 1, 1973 Cal. Stat. 1987 (current version at CAL. CIV. CoDE $\S 1812.30$ (West 1985)).

93. Act of Oct. 1, 1973, ch. 987, 1973 Cal. Stat. 1897, amended by Act of Sept. 23, 1974, ch. 1206, 1974 Cal. Stat. 2609 (codified at CAL. CIv. CoDE $\$ \S 5105,5110,5113.5,5122,5123,5125$, 5127, 5131, 5132 (West 1983)). Section 5125 was amended by Act of Sept. 23, 1986, ch. 1091, 1986 Cal. Legis. Serv. 565 (West) (effective July 1, 1987).

94. CAL. Crv. CoDe § 5125(d) (West 1983), amended by Act of Sept. 23, 1986, ch. 1091, 1986 Cal. Legis. Serv. 565 (West) (effective July 1, 1987) (conferring "primary," rather than "sole," control to the spouse managing the business).

95. CAL. CIV. CODE $\S 5125$ (e) (West Supp. 1987), amended by Act of Sept. 23, 1986, ch. 1091, 1986 Cal. Legis. Serv. 565 (West) (effective July 1, 1987) (specifying the appropriate standard for interspousal transactions).

96. Act of Feb. 1, 1974, ch. 11, 1974 Cal. Stat. 18; and Act of Sept. 18, 1974, ch. 752, 1974 Cal. Stat. 1661 (codified as amended at CAL. PROB. CODE $§ \S 13501,13506,13540-13542,13550-13554$ (West Supp. 1987).

97. Report of the California Comm'N on the Status of Women, California WOMEN 1975, at 19. 
A Report filed in 1977 as part of the national observance of International Women's Year cited these laws, with particular einphasis on the manageinent and control provision, as indicating that "the California situation is probably the best in the nation for inarried woinen at the present time."98 The California legislature, however, had only begun its work directed towards achieving legal equality between women and men. In 1973, the legislature established a Joint Committee on Legal Equahity and directed it to study how California laws, regulations, and admimistrative guidelines might conform with "the principle that equality of rights under the law shall not be denied or abridged on account of sex," to file a report in 1975. The Joint Comittee's work and the work of the California Commission on the Status of Women, as well as sonie of the proposals of the Califorma Law Revision Commission, kept the theme of legal equality before the legislature.

\section{IV \\ Legal Regulation of Marriage, Divorce, AND the FAMILY IN 1987}

In 1987, marriage is one of two recognized family fornis in Califorma. Nonmarital cohabitation is now available as a legally sanctioned alternative. While the property and support riglits of cohabitants arise primarily from private contract, ${ }^{100}$ implied agreements and other equitable reinedies are also available to carry out the parties' reasonable expectations upon termination of their relationship by separation. ${ }^{101} \mathrm{~A}$ growing body of case law continues to define the rights of cohabitants in their interactions with third parties, ${ }^{102}$ their employers, ${ }^{103}$ and the state. ${ }^{104}$ Marriage remains unavailable to same-sex couples, ${ }^{105}$ but open

98. B. Bersch, The Legal Status of Homemakers in California 2 (1977).

99. Assembly Con. Res. No. 33, Res. ch. 114, 1973 Cal. Stat. 3242.

100. Marvin v. Marvin, 18 Cal. 3d 660, 665, 557 P.2d 106, 110, 134 Cal. Rptr. 815, 819 (1976).

101. Id

102. Compare, eg., Butcher v. Superior Court, 139 Cal. App. 3d 58, 70-71, 188 Cal. Rptr. 503, 512 (1983) (cohabitant may recover against tortfeasor for loss of partner's consortium where the nonmarital relationship was a "stable and significant" one) with Ledger v. Tippett, 164 Cal. App. 3d 625, 633-38, 210 Cal. Rptr. 814, 817-20 (1985) (permitting recovery for loss of consortium only in cases of marriage). The issue is pending before the California Supreme Court in Elden v. Sheldon, 164 Cal. App. 3d 745, 210 Cal. Rptr. 755 (1985), hearing granted, No. L.A. 32063 (Cal. Sup. Ct. April 15, 1985).

103. See, eg., Hinman v. Department of Personnel Admin., 167 Cal. App. 3d 516, 213 Cal. Rptr. 410 (1985) (holding that denial of dental benefits to state employee's nonmarital homosexual partner is not unlawful discrimination); see also Achtenberg, Partner Benefits Litigation: Expanding Definitions of the Family, 2 CAL. FAM. L. MoNTHLY 351 (1986) (surveying recent California cases involving right of homosexual partner to employee benefits otherwise available only to spouse).

104. See MacGregor v. Unemployment Ins. Appeals Bd., 37 Cal. 3d 205, 212.15, 689 P.2d 453, 458-59, 207 Cal. Rptr. 823, 828-29 (1984) (plaintiff who left work to accompany her nonmarital partner and their child to another state to care for his elderly and ill father left work for "good cause" and may receive unemployment compensation); Norman v. Unemployment Ins. Appeals Bd., 
cohabitation is probably more frequent since sodomy laws affecting consenting adults were repealed in 1975. ${ }^{106}$ Municipal ordinances that allow the registration of "Doinestic Partnerships"107 provide at least soine legal recognition of gay and lesbian couples, and an effort is underway to secure for them the right to marry. ${ }^{108}$

Within marriage, the drive for legal equality has produced important rights for women. The husband is no longer recognized as the head of the family. ${ }^{109}$ The 1973 law $^{110}$ extending equal management and control over the community property to wives was strengthened and expanded in 1986, ${ }^{111}$ creating a cause of action for mismanagement, as well as a clear right to an accounting, during the functioning marriage. In addition, judicial decisions have expanded the concept of community property to include nonvested pensions, ${ }^{112}$ military "retired pay," 113 and other employment benefits. ${ }^{114}$ A statutory right of reimbursement exists to recover community contributions to the education of one of the spouses, ${ }^{115}$ but neither a professional degree nor the enhanced earning capacity it represents has been classified as a community property asset. $^{116}$

The criminal law now prohibits marital rape, ${ }^{117}$ and victimis of

34 Cal. 3d 1, 6-9, 663 P.2d 904, 907-09, 192 Cal. Rptr. 134, 137-39 (1983) (plaintiff who accompanied her nonmarital partner to another state where he had found work did not leave work for "good cause" absent showing of impending marriage or the existence of a parent-child family relationship).

105. CAL. Civ. CoDE $\S 4100$ (West 1983 \& Supp. 1987).

106. Act of May 12, 1975, ch. 71, \& 7, 1975 Cal. Stat. 131, 133 (codified as anieuded at CAL. Penal CoDe $\S 286$ (West Supp. 1987)).

107. See City of West Hollywood Ordinance No. 22 (Establishing Regulations Governing the Creation, Termination and Effect of Domestic Partnerships (Feb. 21, 1985) (copy on file with author); see also New York Times, March 19, 1985, at A16, col. 1.

108. San Francisco Chron., Oct. 29, 1986, at 3, col. 3 (reporting that the American Civil Liberties Union has decided to advocate legalizing homosexual marriage).

109. Act of Oct. 1, 1973, ch. 987, § 2, 1973 Cal. Stat. 1897, 1898, repealing former CAL. Civ. CODE $\S 5101$.

110. Act of Oct. 1, 1973, ch. 987, $\S 14,1973$ Cal. Stat. 1897, 1901 (codified as aniended at CAL. Crv. CODE $\S 5125$ (West 1983 \& Supp. 1987)); see also supra text accompanying notes 93-95.

111. Act of Sept. 23, 1986, ch. 1091, 1986 Cal. Legis. Serv. 565 (West) (codified as aniended at CAL. Civ. CoDE $\S \S 5125-5125.5$ (West Supp. 1987) (effective July 1, 1987)).

112. In re Marriage of Brown, 15 Cal. 3d 838, 544 P.2d 561, 126 Cal. Rptr. 633 (1976).

113. In re Marriage of Fithian, 10 Cal. 3d 592, 517 P.2d 449, 111 Cal. Rptr. 369, cert. denied, 419 U.S. 825 (1974).

114. See, e.g., In re Marriage of Skaden, 19 Cal. 3d 679, 566 P.2d 249, 139 Cal. Rptr. 615 (1977) (insurance sales agent's termination pay); In re Marriage of Horn, $181 \mathrm{Cal}$. App. 3d 540, $226 \mathrm{Cal}$. Rptr. 666 (1986) (professional football player's severance pay); Marriage of Foster, 42 Cal. App. 3d 577, 117 Cal. Rptr. 49 (1974) (professional goodwill).

115. CAL. Civ. Code $\S 4800.3$ (West Supp. 1987).

116. See In re Marriage of Sullivan, 37 Cal. 3d 762, 691 P.2d 1020, 209 Cal. Rptr. 354 (1984); In re Marriage of Aufmuth, 89 Cal. App. 3d 446, 152 Cal. Rptr. 668 (1979); Todd v. Todd, 272 Cal. App. 2d 786, 78 Cal. Rptr. 131 (1969).

117. Cal. Penal Code $\S 262$ (West Supp. 1987). 
domestic violence, whether married or not, have gained some legal protection against abuse. ${ }^{18}$ The California courts have refused, however, to allow expert testimony that a victim suffers from rape trauma syndrome as evidence that a rape occurred. ${ }^{119}$

In 1975, California adopted the Uniform Parentage Act, ${ }^{120}$ abolishing the legal status of illegitimacy, ${ }^{121}$ and, in general, equahizing the legal control exercised by both natural parents over their children. ${ }^{122}$ The policies articulated in the Act led the California Supreme Court to abolish the rule that a child autornatically assumes the father's surname at birth. ${ }^{123}$ In addition, both parents now have an "equal responsibility" to support their children. ${ }^{124}$ Spouses are hable for their inutual support during the marriage relationship. ${ }^{125}$

The Family Law Act itself has been amended many times since 1970. For example, the legislature has eliminated two of the three instances in which fault could be used as a factor in the proceedings. Evidence of fault is no longer adımissible to determine the existence of irreconcilable differences, ${ }^{126}$ nor can it be used to modify or revoke spousal support where the supported spouse is hiving in nonmarital cohabitation with another person and holding himself or herself out as married to that person. ${ }^{127}$ Since 1969, the legislature has also expanded

118. The Domestic Violence Prevention Act, CAL. Clv. Pro. Code $§ \S 540-553$ (West Supp. 1987).

119. People v. Bledsoe, 36 Cal. 3d 236, 251, 681 P.2d 291, 301, 203 Cal. Rptr. 450, 460 (1984).

120. Uniform Parentage Act, ch. 1244, §11, 1975 Cal. Stat. 3194, 3196-3204 (codified as amended at CAL. Crv. CODE $\S \S 7000-7018$ (West 1983 \& Supp. 1987)).

121. CAL. Clv. CoDE $\S 7002$ (West 1983).

122. See, e.g., CAL. CIv. CODE $\S 7017$ (West Supp. 1987) (extending to presumed fathers the adoption rights provided to natural mothers at CAL. CIv. CoDE $\S \S 221-230.8$ (West 1983 \& Supp. 1987)). A man claiming to be the natural father, but who is not a presumed father, may bring an action to have his paternity determined if the natural mother relinquishes the child for adoption. See CAL. CIv. CODE \& 7006(d) (West Supp. 1987) (excepting cases falling within the conclusive presumption of legitimacy established by CAL. EvID. CODE $\S 621$ (West $1966 \&$ Supp. 1987)). The conditions for presumptive fatherhood are set out at CAL. CIV. CODE $\S 7004$ (West 1983). If the court finds that the adoption is in the child's best interests, it shall order that the natural father's consent is not required; such a finding termmates the natural father's parental rights and responsibilities. See CAL. CIV. CODE $\$ 7017$ (d)(2) (West Supp. 1987) (reversing the contrary holding that the provisions of CAL. CIv. CODE $\$ 4600$ (West Supp. 1987) apply to proceedings under $\$ 7017$ in In re Baby Girl M., 37 Cal. 3d 65, 69-73, 688 P.2d 918, 921-23, 207 Cal. Rptr. 309, 312-14 (1984)).

123. In re Marriage of Schiffinan, 28 Cal. 3d 640, 697, 620 P.2d 579, 583, 169 Cal. Rptr. 918, 922 (1980).

124. CAL. Civ. Code $\S \S 196,196 a$ (West 1983).

125. CAL. Civ. Code $\$ 5100$ (West 1983).

126. Act of Apr. 18, 1975, ch. 35, 1975 Cal. Stat. 59 (codiffed as amended at CAL. Crv. Codz $\S 4509$ (West 1983)).

127. Act of Dec. 3, 1971, ch. 1675, § 2, 1971 Cal. Stat. 3600, 3601-02 (codified as amended at CAL. CIv. CODE $\S 4801$ (West Supp. 1987)). The supported spouse's cohabitation with a person of the opposity sex does, however, give rise to a rebuttable presumption of decreased need for support. CAL. Civ. CODE $\S 4801.5$ (West Supp. 1987). 
the list of factors to be considered in awarding spousal support, ${ }^{128}$ and the court may be required to make factual findings with respect to each factor. ${ }^{129}$ As an enforcement measure, the court may order a wage assignment or payment through a county official. ${ }^{130}$

The requirement that the community and quasi-community property be divided equally remains in the law with its two original exceptions. ${ }^{131}$ The legislature has added an additional exception: where the net value of the property is less than $\$ 5000$, and one party cannot be located, the entire community estate may be awarded to the other party. ${ }^{132}$ In addition, certain assets receive special treatment in the division of property. At least one-half of community property personal injury dainages must be assigned to the mjured spouse, and the entire amount shall be so awarded, unless the court finds that the interests of justice require another disposition. ${ }^{133}$ The family residence is within the equal division rule, ${ }^{134}$ but the legislature has authorized a special "family home award" that allows the court to grant temporary use of the home to the custodial spouse and children. ${ }^{135}$

The jurisdiction of the divorce court now extends to separate prop-

128. Compare Family Law Act, ch. 1608, $\$ 4801,1969$ Cal. Stat. 3312, 3314-44 (noting two judicial factors) with CAL. Crv. CODE $\S 4801$ (a) (West Supp. 1987) (listing eight judicial factors).

129. CaL. Civ. CoDE $\S 4801$ (a) (West Supp. 1987).

130. CaL. Civ. Code $\S \S 4801.6,4801.7$ (West Supp. 1987).

131. CaL. Crv. CoDe $\S 4800$ (a)-(b)(2) (West Supp. 1987).

132. CAL. Civ. CODE $\S 4800$ (b)(3) (West Supp. 1987).

133. CAL. Civ. CoDE $\S 4800(b)$ (4) (West Supp. 1987). A sinilar provision was enacted briefly in Act of July 3, 1968, ch. 457, § 146(c), 1968 Cal. Stat. 1077, repealed by Act of Sept. 4, 1969, ch. $1608, \S 3,1969$ Cal. Stat. 3312, 3313, but the Family Law Act, which replaced this provision, omitted any requirement that the mjured spouse receive at least one-half of the personal injury damages. See Family Law Act, ch. 1608, §4800, 1969 Cal. Stat. 3312, 3333 (amended 1970). Judicial commentators criticized this change from prior law, see ATTORNEY'S GUIDE, supra note 74, at 158-59, and the legislature restored the former directive in its present form. Act of Sept. 14, 1970, ch. 962, § 3, 1970 Cal. Stat. 1725, 1725-26 (codified as amended at CAL. CIV. CoDE $\S 4800(b)(4)$ (West Supp. 1987)).

134. See ATTORNEY's GUIDE, supra note 74, at 159-61 (arguing that the only way to obtain an exception to the equal division rule as it applied to the family home was by filing a declaration of marital homestead to permit the court to dispose of the home under CAL. Civ. CoDE $\S 4808$ rather than $\$ 4800$ ). The Assembly Committee on Judiciary issued a special report to repudiate this "misconception," and to indicate that its intent had been to permit the family home to come within the statutory exception to CAL. CIV. CODE $\$ 4800$ that permits a court to award "any asset to one party on such conditions as the court deems proper to effect a substantially equal division of the property." Assembly Comm. on Judiciary Report on A.B. No. 530 and S.B. No. 252 (The Family Law Act), 1970 Reg. Sess., 1 Cal. Assembly Daily J. 785, 787 (1970). Citing this passage in the Conmittee Report, the court in In re Marriage of Boseman, 31 Cal. App. 3d 372, 375 n.1, 107 Cal. Rptr. 232, 234 n.1 (1973), permitted the wife to live in the family home, the sole coinmunity asset, with the children until the youngest child reached majority.

135. Act of July 16, 1984, ch. 463, 1984 Cal. Legis. Serv. 230 (West) (codified as amended at CAL. CIv. Code $\S 4800.7$ (West Supp. 1987)). 
erty held in joint tenancy or tenancy in common. ${ }^{136}$ A summary dissolution procedure, which allows divorce based on inutual consent, is available to spouses inarried for five years or less, who have no children, and who own a relatively sinall community estate. ${ }^{137}$

Ten years after it began the trend toward no-fault divorce, the California legislature led the way toward shared parenting after divorce by enacting the country's first coinprehensive joint custody law. ${ }^{138}$ Six inonths later, it imposed mandatory inediation in contested cases involving child custody or visitation. ${ }^{139}$ The California Supreine Court has insisted that in awarding sole custody, trial courts consider the circuinstances of the cases free of sex role stereotypes. ${ }^{140}$

Divorced fathers were among the inajor proponents of joint custody; ${ }^{141}$ they saw the legislation as a logical extension of the no-fault philosophy. ${ }^{142}$ While soine feminists doubt that joint custody laws are in the best interests of women or children, ${ }^{143}$ others betieve that some woinen will gaim greater independence if fathers assume an equal role in child rearing both during marriage and after divorce. ${ }^{144}$ Mandatory inediation and joint custody, however, may hold special dangers for women in families where domestic violence has occurred. ${ }^{145}$

Finally, in the area of child support, the Agnos Child Support Stan-

136. Act of July 29,1985 , ch. $362, \S 3,1985$ Cal. Legis. Serv. $349,351-52$ (West) (codified at Cal. Civ. Code $\S 4800.4$ (West Supp. 1987)).

137. Act of Aug. 21, 1978, ch. 508, § 2, 1978 Cal. Stat. 1654, 1655-57 (codified as amended at Cal. Civ. CoDe $\$ 4550-4556$ (West 1983 \& Supp. 1987)).

138. Act of Sept. 21, 1979, ch. 915, 1979 Cal. Stat. 3149 (codified as amended at CAL. Civ. CODE $\$ \S 4600,4600.5$ (West Supp. 1987)). A few states had enacted statutes authorizing joint custody before the California law was passed. See Folberg \& Graham, Joint Custody of Children Following Divorce, 12 U.C. DAvis L. REV. 523, 542-44 (1979). California's statute was the first to create a presumption that joint custody is in the best interests of children where both parents have requested such an award and have developed an appropriate joint custody plan. See Lemon, Joint Custody as a Statutory Presumption: California's New Civil Code Sections 4600 and 4600.5, 11 Golden Gate U.L. ReV. 485, 485-91 (1981).

139. Family Conciliation Court Law, ch. 48, § 5, 1980 Cal. Stat. 126, 133-34 (1980)(codified as amended at CAL. Civ. Code $\S 4607$ (West Supp. 1987)).

140. See, e.g., In re Marriage of Carney, 24 Cal. 3d 725, 736-40, 598 P.2d 36, 42-44, 157 Cal. Rptr. 383, 389-91 (1979) (reversing order which denied custody to handicapped father in part because of his inability to go fishing or to play ball with his two sons).

141. See generally M. Roman \& W. Haddad, The Disposable Parent: The Case for JoINT CusToDY (1978).

142. See Cook, California's Joint Custody Statute, in JoINT CustodY AND SHARED PARENTing 168, 170 (J. Folberg ed. 1984).

143. See, e.g., Schulmann \& Pitt, Second Thoughts on Joint Custody: Analysis of Legislation and Its Implications for Women and Children, in JOINT CuSTODY AND SHARED PARENTING, supra note 142, at 209; see also Lemon, supra note 138 at 527-31.

144. See Bartlett \& Stack, Joint Custody, Feminism and the Dependency Dilemma, 2 BERKRLEY WOMEN's L.J. 9 (1986) (discussing feminist critique of joint custody).

145. See Gerniane, Johnson \& Lemon, Mandatory Custody Mediation and Joint Custody Orders in California: The Danger for Victims of Domestic Violence, 1 BERKELEY WOMEN's L.J. 175, 188-94 (1985). 
dards Act of $1984^{146}$ established a formula for mandatory mimimum child support awards. A court may award higher amounts in appropriate cases. ${ }^{147} \mathrm{~A}$ court may not, lowever, use a parent's more favorable financial position as the basis of a custody award. ${ }^{148}$

This brief sketch of California laws regulating the family in 1987 shows that the theine of equality between women and men assumed prominence in Califorma family law reform only after the adoption of the no-fault divorce law in 1970. This theme lias contributed to laws that are designed to ensure substantial equality, ratlier than fornial equality, by taking into account the concrete circumstances of family life. These laws, in turn, have facilitated the development of a public policy favoring private ordering of family arrangements. ${ }^{149}$ A welcome freedom permits experimentation witli a variety of family forms.

If the no-fault philosophy was aliead of its time when the Family Law Act became effective in 1970, the social and legal clianges that liave followed in its wake liave produced a context in which it is now entirely appropriate. Altliough inequities persist under the no-fault system, to return to fault as a determinative factor in divorce in 1987 would be illadvised and unwise. ${ }^{150}$ The task that lies ahead is ratlier one of devising ways to prevent financial and emotional harm to spouses whose clioices were made at an earlier time and in light of more traditional expectations about the roles of woinen and men. Women in "traditional" marriages are prominent among those Weitzman lias identified as the victims of the no-fault revolution. ${ }^{151}$ I turn now to some proposals for improving their situation, bearmg in mind that the clioices and expectations that produced their condition may be less popular among couples in the future than they were in the past. ${ }^{152}$

146. Agnos Child Support Standards Act of 1984, ch. 1605, § 4, 1984 Cal. Legis. Serv. 557, 55864 (West) (codified as amended at CAL. Crv. CoDE $\$ \S 4720-4747$ (West Supp. 1987)). The court may order wage assignments as an enforcement measure. CAL. Crv. CoDE $\S$ 4701(a) (West Supp. 1987 ).

147. Cal. Civ. CoDe $\S 4724$ (West Supp. 1987).

148. Burchard v. Garay, 42 Cal. 3d 531, 539, 724 P.2d 486, 491-92, 229 Cal. Rptr. 800, 805-06 (1986) (reversing order awarding custody to father in part because of his favorable economic position).

149. See generally Shultz, Contractual Ordering of Marriage: A New Model for State Policy, 70 CALif. L. REV. 204 (1982).

150. Weitzinan found that the people she interviewed-California lawyers, judges, and divorcing couples- "strongly approve of the principles of divorce without fault, grounds, or consent, and they overwhelmingly consider this aspect of the present legal system to be appropriate and fair."

L. WEITZMAN, supra note 13, at 383.

151. Id. at 380-81 (describing the situation of the "long-married older housewife with little or no experience in the paid labor force, who has devoted herself to ler liusband, home, and children in the expectation that she would share whatever income and assets the couple acquires").

152. Households composed of married couples with children have declined faster than any other type of household since 1970 . Such houselolds declined from $25,532,000$ in 1970 to $24,210,000$ in 1985, a decrease of $5.5 \%$, while single-parent houseliolds, louseholds of persons living alone, and 


\section{Proposals For Further ReForm}

Weitzman has offered recommendations for rectifying the injustices she identified in the application of California's divorce law. ${ }^{153}$ Some of her recommendations, such as setting adequate child support awards and strengthening their enforcement, ${ }^{154}$ are sound and deserve to be implemented. Otlier proposals, like programs for educatimg judges in the exercise of their discretionary power to set support awards, ${ }^{155}$ are helpful and

households of unrelated persons all increased. San Francisco Chron,. Nov. 5, 1986, at 19, col. 1 (citing a Census Bureau Report). See also Kay, supra note 9, at text preceding note 384 (arguing that the law should not encourage couples who narry in the future to make choices that produce female dependency at divorce).

153. L. WeItZMan, supra note 13 at 378-400. The California Senate created a Task Forec on Family Equity and charged its members to "review recommendations based on the book, The Divorce Revolution: The Unexpected Social and Economic Consequences for woinen and Children in America, and [to]. . . develop specific proposals for those revisions of state law it deems necessary after review of the recommendations." Cal. S. Res. No. 28, §4, 1985-86 Reg. Sess.. The Final Report of the Task Force is expected to be available by the end of April, 1987 (letter to author from Ms. Joanne Schulman, March 26, 1987, on file in with author). Some bills that reflect the Task Force's legislative proposals, however, have been introduced into the 1987-88 regular session. A few of these bills are discussed infra at notes 155 (S.B. 1209), 173 (S.B. 907), 182 (S.B. 1615), 188 (S.B. 1341) and 196 (S.B. 1296).

One commentator has challenged Weitzman's assumption that the problems she identifled can be corrected by further legislation, arguing instead that inajor cultural changes concerning gender must precede any ineaningful legal change. Fineman, Elusive Equality, 1986 AM. B. FouND. RES. J. (forthcoming) (symposium issue on Weitzman's Divorce Revolution). I share Finennan's view that cultural change in our attitude toward gender is ultimately required in order to construct a society in which woinen and men can be equals beforc the law, see Kay, supra, note 9 at text accompanying notes 386-435. Nevertheless, I agree with Weitzman that soine intermediate legislative improvements can be proposed that are desirable to umeliorate existing conditions.

154. L. WertzMAN, supra note 13, at 391-93. I am not convinced, however, of the wisdom of Weitzman's proposal that divorced parents should bear an obligation not imposed on married parents to support their children through a college education. See Moore, Parents' Support Obligations to Their Adult Children, 19 AKRON L. REv. 183, 190-95 (1985) (arguing that such laws are unfair). Perhaps all parents should remain responsible for their children's educational expenses until the children reach a designated age or attain a particular level of education, whichever occurs first. Professor Carol Brnch has indicated in legislative testimony that she favors legislation that would give all young adult children a right to parental assistance for the purposes of education or training, whether or not they are members of an intact family. She went on to point out, however, that if such a comprehensive provision is not politically feasible, she would urge that the "inportant first step" be taken of preventing discrimination against children of separated fanilies. Interim Hearings on Child Support Before the California Assembly Judiciary Committee, 1986-87 Reg. Sess., (written testimony of Carol S. Brnch, March 18, 1987); see also Coinment, In Support of Educatlon: An Examination of the Parental Obligation to Provide Postsecondary Education in California, 18 PACIFIC L.J. 377, 394 (1987) (criticizing two bills introduced into the 1985-86 regular legislative session in California that would have authorized continuation of child support beyond majority to cover edueational expenses in certain cases, and proposing instead the continuation of support for an adult child who is dependent upon his or her parents while enrolled in school).

155. L. WerTZMAN, supra note 13, at 395-98. Recognizing the limitation of this approach, Weitzman recomınends that judges assigued to family law calendars be required to have "prior experience, knowledge and interest in family law" and that they be able to hire special coinmissioners to assist thein. Id. at 398. This recommendation is consistent with the 1966 proposal 
should be seriously considered by the Judicial Council. I comment below on a few of Weitzman's proposals that seem to me either less obviously desirable or in need of inodification.

Weitzman supports the equal division principle, rather than the equitable distribution provisions adopted by many other states, in part because women fare better under an equal division law. ${ }^{156}$ She contends, however, that the failure to expand the definition of property to include "career assets," 157 such as pensions, goodwill, medical and dental insurance, and a professional degree or hicense (with the enhanced earning capacity it represents), "Inakes a mockery of the equal division rule."158

All of the items that Weitzman characterizes as career assets, except the last, are considered property in Califorina. ${ }^{159}$ As for a professional education, degree, or hicense obtained during the marriage, with its resulting increase in earning capacity, the California Law Revision Coinmission considered and rejected a proposal to define those items as property in 1983. Among its reasons for rejecting the proposal, the Commission cited the creation of problems of management and control, creditor's rights, taxation, disposition at death, and valuation upon dissolution. ${ }^{160}$ It also argued that

to give the working spouse an interest in half the student spouse's increased earnings for the remainder of the student spouse's life because of the relatively brief period of education and training received during marriage is not only a windfall to the working spouse but in effect a permanent inortgage on the student spouse's future. ${ }^{161}$

Instead, the Commission proposed, ${ }^{162}$ and the legislature enacted, ${ }^{163}$ a ineasure requiring the student spouse to reimburse the community upon dissolution for the community expenditures toward education and training.

Like Weitzman, I view as unfair the situation of the supporting spouse (usually a wife) who has worked to support the family while the

of the Governor's Commission on the Family for a Family Court. See supra note 68. Weitzman's proposal for judicial training would be implemented by S.B. 1209 (1987-88 Reg. Sess.), requiring the Judicial Council to establish an annual one-week judicial training and education program in family law that includes instruction on the effects of gender bias on family law proceedings and the econornic consequences of dissolution.

156. L. WEITZMAN, supra note 13, at 47-49; see also Glendon, Family Law Reform in the 1980's, 44 LA. L. REV. 1553, 1555-56 (1984) (criticizing equitable distribution schemes).

157. L. WEITZMAN, supra note 13 , at 387-88.

158. Id. at 388 (emphasis omitted).

159. See supra text accompanying notes 112-14.

160. Recommendation Relating to Reimbursement of Educational Expenses, $17 \mathrm{CAL}$. L. Revision CoMmission ReP. 233, 234 (1983).

161. Id.

162. Id. at 235-38.

163. Act of Sept. 30, 1984, ch. 1661, 1984 Cal. Legis. Serv. 207 (West) (codified at CAL. Civ. CODE $\S 4800.3$, and amended at CAL. Civ. CODE $\S \S 4800,4801$ (a)(1) (West Supp. 1987)). 
student spouse (usually a husband) attends professional school, and who is divorced before the student spouse begins to produce the increased level of family incoine that is expected froin professional practice. Such a wife has foregone the immediate incoine that her spouse might have produced had he worked instead of attending school and the expected future incoine that she might have earned had she used her time in professional training. Moreover, if the divorce occurs soon after her husband completes his studies, there is typically no accumulated property available for distribution. Finally, because the working wife has deinonstrated her capacity for self-support, she may not be ehigible for spousal support. Thus, the husband will leave the inarriage with his enhanced professional earning capacity intact, and without any future obligations to his former wife.

The unfairness of this scenario stimulated proposals to justify a financial award to the wife. Professor Joan Krauskopf based her theory of compensation on the insight of economists, that the systematic developinent of a person's skill, talents, and knowledge to increase future productivity constitutes an investment in human capital and is therefore a form of wealth. ${ }^{164}$ Similarly, economists view the family uinit as a firm in which decisions are made to inaximize the utility of the unit as a whole, rather than the nidividual welfare of each member. ${ }^{165}$ Thus, a wife who undertakes to support the family while her husband acquires a professional degree may be miplenenting a decision that the family firm will benefit inore fron an investinent in his hunian capital than in her own. Instead of exploiting her own potential, she has chosen, with her husband's express or tacit consent, to invest her time, energy, and effort in his development. Krauskopf noted that economists had not explored the consequences of their "family as firm" model for divorce. ${ }^{166}$ She concluded that the wife's investnent in the husband's human capital should not be lost upon divorce, ${ }^{167}$ but should be recognized in a financial award, preferably through an award of gross maintenance. ${ }^{168}$

It is not clear, however, that the economic concept recoginizing a student's investnent in his or her own potential as a form of wealth can be extended without modification to enconipass the investment of another person in that potential. At the very least, Weitzman's proposal that the investment be characterized as property is troublesome if taken hterally. Our law rejected the notion that one person can have a prop-

164. See Krauskopf, Recompense for Financing Spouse's Education: Legal Protection for the Marital Investor in Human Capital, 28 U. KAN. L. REV. 379, 381-82 (1980).

165. Id. at 386-88.

166. Id. at 388 .

167. Id.

168. Id. at 417 
erty right in the labor of another when slavery was abolished. ${ }^{169}$ In the context of marriage, the long struggle to emancipate married women from their liusband's ownership of their property and services lias not yet been fully completed. The wife's unpaid services in the lome remain an expected element of the conventional marriage contract, even thougli no legal action exists that permits the husband to compel her specific performance. ${ }^{170}$ It would seem a step backward now to propose that the wife, by her investment in the husband's education, sliould acquire a hiteral property right in his future labor. ${ }^{171}$

Moreover, the characterization of an asset as property subject to division upon divorce even though tliat asset can realize its value only through its holder's future labor is inconsistent with the no-fault philosophy that seeks to achieve a clean break between spouses to enable each to begin a new life. ${ }^{172}$ While the presence of children may prevent a clean break as far as the parental relationship is concerned, ${ }^{173}$ especially if joint

169. U.S. CoNST. amend. XIII.

170. Sayre, Property Rights of Husband and Wife, 6 Marriage \& Family Living 17, 17-18 (1944), reprinted in SELECTED ESSAYS ON FAMILY LAW 503, 504 (1950).

171. The great majority of states that have considered the matter have refused to characterize a professional degree and license as property subject to division on divorce. See Kay, supra note 9, at note 368 (listing 19 states, including California, that liave rejected a property classification, and four states, including New York, that lrave accepted such a classification). The New York Court of Appeals limited its holding that a professional degree and license constitute "inarital property" subject to division on divorce to an interpretation of the legislative intent underlying New York's Equitable Distribution Law. O’Brien v. O’Brien, 66 N.Y.2d 576, 583, 489 N.E.2d 712, 715, 498 N.Y.S.2d 743, 746 (1985). The court pointed out that neither decisions from other states nor traditional concepts of property were controlling "because decisions in other States rely principally on their own statutes, and the legislative history underlying them, and because the New York Legislature deliberately went beyond traditional property concepts wlien it fornulated the Equitable Distribution Law." Id. One commentator claims that the O'Brien court's interpretation of the statute was erroneous becanse it "intermingled the process of classifying marital property with that of distributing it." Comment, Not What the Doctor Ordered-Medical License Declared Marital Property: O'Brien v. O'Brien, 60 ST. JoHN's L. Rev. 539, 545 (1986).

172. See Comnnent, Half a Loaf Is Better Than None: Sullivan Revisited, 15 GoldEN GATE U.L. REv. 527, 544-46 (1985) (arguing that property awards based on future earnings are contrary to the concept of California law that income acquired after divorce or separation is separate property).

173. See Glendon, supra note 156 , at 1558 ("The idea of effecting a clean break by dividing property between the sponses and excluding maintenance after divorce does not come to grips witl the fact that no legal system lias been able to aclieve this result on a widespread basis because, in most divorce cases, children are present and there is insufficient property"). As the text indicates, my proposal does not exclude the realization that spousal support will often be necessary. See, e.g., In re Marriage of Ramer, 187 Cal. App. 3d 263, 273, 231 Cal. Rptr. 647, 652 (1986) (rejecting husband's argument that a rule including his new wife's earnings for the purpose of computing the anount available for spousal support to lis first wife would deter remarriage with the comment, "[a]s to deterring remarriage, we can only say that to the extent the rule makes persons realize that they inay not pursue their own pleasures in utter disregard of an earlier marriage of 22 years that lias produced four clildiren and a dependent spouse, it is to bc commended rather than faulted"). Indeed, S.B. 907 § 2(d) 1987-88 Reg. Sess. proposes an amendment to CAL. CIv. CODE $\$ 4801$ that requires a court to retain jurisdiction indefinitely over a spousal support order, absent a contrary written agreement, where the inarriage lias been of long duration. 
custody, as well as spousal and child support, is ordered, ongoing financial relationships between the divorced spouses should be minimized. Giving the supporting spouse a property interest in the student spouse's future income hampers the ability of each spouse to begin a new life. The presence of children requires the close personal interaction of both divorced parents only for the limited period of the children's minority, and spousal support normally ends upon the remarriage of the supported spouse. In contrast, the recogintion of a property relationship in the future income of a professional spouse could endure until that spouse dies.

The Califorma legislature's solution to the career-asset problem is to reimburse the community only for actual out-of-pocket educational expenses paid from community funds. ${ }^{174}$ This is insufficient to make the supporting spouse whole. As one commentator has poinited out, the statutory remedy does not reimburse the community for the student spouse's intellectual effort and time devoted to acquiring a professional education. ${ }^{175}$ Since a married person's time, effort, and energy constitute a community asset, the commentator analogizes the student's use of that asset to further his or her education to a spouse's use of community funds to improve his or her separate real property. In the latter case, the spouse continues to hold the improved real estate as separate property, but the community acquires an equitable right to reimbursement of the community funds expended or to recovery of the enhanced value of the asset. Thus, by analogy, the professional degree and license should be classified as the student spouse's separate property, even though acquired during marriage, but the community should acquire a right to be rein1bursed for the benefit conferred by the student's efforts, to be measured by the increase in the student's earning capacity attributable to the degree. ${ }^{176}$

Though the offered analogy is provocative, I am not convinced that it is necessary or desirable to characterize a professional degree and license as separate property improved by a community property asset in order to safeguard the student spouse's claim to those assets after divorce and achieve fairness to the supporting spouse. It is conceptually troublesome to characterize an asset acquired during marriage, in part through the efforts of a spouse, as separate property. Moreover, the argument imphes that, if the education and license were obtanied prior to marriage, the professional spouse wonld be entitled to claim part of his or her postmarital income as separate property attributable to separate property capital. Such a result would undercut the basic assumption of the con1-

174. See supra note 163.

175. See Comment, supra note 172 , at 557-58.

176. Id. at $569-70$. 
1nunity property system that income resulting from postmarital labor is produced by the combined efforts of both spouses.

Rather than focus on the gain enjoyed by the student spouse and atteinpt to enable the supporting spouse to participate in that gain as a co-owner, ${ }^{177}$ I suggest that we emphasize instead the loss incurred by the supporting spouse and devise rules that require the student spouse to make up that loss. By focusing on the loss, we inay be able to tailor the reinedy more closely to the injury. As others have pointed out, ${ }^{178}$ the supporting spouse's loss inay include the opportunity cost of having foregone her own education to improve her earning capacity, as well as wages foregone by the student spouse during the education years that would lave enhanced the family's standard of living. These are personal losses incurred by the supporting spouse, and they slould be made up in the form of a lunip sum award, ${ }^{179}$ or, at her option, by having her own educational and living expenses paid during her period of professional training. ${ }^{180}$ Some courts liave already suggested sucl1 an approach. ${ }^{181}$ In Califorma, the existing statutes seein broad enough to permit courts to implement this suggestion without further ainendment. ${ }^{182}$

177. The difficulty of placing a precise monetary value on the degree is itself a reason for seeking a different approach to the problem. See Mullenix, The Valuation of an Educational Degree at Divorce, 16 LOY. L.A.L. REV. 227, $259-74$ (1983) (reviewing and rejecting proposed methods of valuation). The approach proposed in the text is somewhat speculative as well, but it focuses on past, rather than future, choices and alternatives. As a result, my approach may be more realistic since it is limited by the necessity of taking account of historical, rather than hypothetical events.

178. See Bruch, The Definition and Division of Marital Property in California: Towards Parity and Simplicity, 33 HASTINGS L.J. 769, 818 (1982); Krauskopf, supra note 164, at 384-88.

179. See Bruch, supra note 178 , at 821 n.203. In my view, the lump sum award should be treated as a debt owed to the supporting spouse that is assigned to the student spousc for repayment, rather than be counted as part of the property division or as spousal support.

180. The Law Revision Commission observed that, if the student spouse in turn has supported the working spouse during his or her education, "there is in effect an offset and it inakes hittle sense to require each to reimburse the other." Recommendation Relating to Reimbursement of Educational Expenses, supra note 160, at 236. Accordingly, the statute permits the reimbursement to be reduced or modified if "[t] he education or training received by the party is offset by the education or training received by the other party for which commumity contributions have been made." CaL. Clv. CODE $\S 4800.3$ (c)(2) (West Supp. 1987). It seems appropriate, therefore, that the working spouse should be able to elect this offset as a remedy in heu of the statutory reinburseinent claim.

181. See, e.g., Stevens v. Stevens, 23 Ohio St. 3d 115, 120-21 at n.7, 492 N.E.2d 131, 135-36 at n.7 (1986) (citing L. WEITZMAN, supra note 13).

182. Cal. Crv. Code $\S 4800.3$ (d) (West Supp. 1987) provides in part that "nothing in this subdivision shall linit consideration of the effect of the education, training, or enhanceinent, or the amount reimbursed pursuant to this section, on the circumstances of the parties for the purpose of an order for support pursuant to Section 4801." CAL. CIV. CoDE $\$ 4801$ (a)(1)(C) and (A) (West Supp. 1987), respectively, list among the circumstances relevant to spousal support the extent to which a spouse contributed to the other spouse's attainment of an education, training, career position, or license and the time and expense required for the supported spouse to acquire appropriate education, training, retraining, and employment. These sections, read together, permit the court to order the student spouse to underwrite the supporting spouse's education even if, absent that spouse's withdrawal from the labor market to attend school, she would be capable of self- 
Moreover, this approach offers a basis for rectifying another of the situations Weitzman has identified as unfair-that of the wife divorced after a lengthy marriage who has foregone her own economic self-development in order to devote herself to the role of a full-time homemaker and mother. ${ }^{183}$ She, too, has suffered an economic disadvantage, even though she did not work outside the home to support the family while the other spouse acquired an education that enhanced his future earning capacity. If at the end of a lengthy marriage there is insufficient property to provide for her needs, and if she is not capable of being trained for selfsupport, she will suffer a financial loss. When the wife has incurred such a loss because she coinplied witl her husband's request to assume a traditional marital role, he should reimburse her. Even if the wife freely chose to neglect lier own economic self-development im order to give priority to lier family, she should still be reimbursed for her opportunity loss. Most women who made such traditional clioices in the past did so in the context of strong cultural expectations that such clioices were proper ones for married women. As Weitzinan's data convincingly deınonstrate, ${ }^{184}$ women who followed those cultural norms have been disadvantaged as a result of marriage and child rearing. It seens fair to expect their husbands, whose economic self-development was facilitated by that allocation of marital roles, to reimburse them. ${ }^{185}$

While I agree witl Weitzman that the homemaking spouse should receive reimbursement for lier lost opportunities, I have difficulty with lier proposal that the lomemaking spouse should also obtain the fanily home as an exception to the rule requiring an equal division of property. ${ }^{186}$ As I noted earlier, ${ }^{187}$ existing California law autliorizes a court

support. S.B. No. $1615, \S 1$ (g) Reg. Sess. $1987-88$ would amend CAL. CIV. CoDE $\S 4801$ to authorize the court to order payment of all or part of the necessary expenses for training or education that is reasonably calculated to enhance the earning capacity of a party seeking spousal support.

183. See supra note 151 .

184. See L. WeITZMAN, supra note 13 , at 330-36.

185. At least one court has so held. See In re Marriage of Williams, 714 P.2d 548, 550.53 (Mont. 1980) (affirming maintenance award of $\$ 162,597$ to wife to compensate her for her foregone career in art or teaching, calculated on the basis of expert testimony as $\$ 76,313$ in lost retirement benefits and $\$ 86,284$ in salary differential between what she would have earned had she continued her outside employment during the marriage and what she will be able to earn after divorce). The wife in Williams did not work outside the home during the eighteen years of the marriage, but remained at home to care for the parties' six children. This type of award is facilitated in California by CAL. CIv. CODE $\S 4801(\mathrm{a})(1)$ (B) (West Supp. 1987), which provides in part that a circumstance to be taken into account when setting the spousal support award is "[t]he extent to which the supported spouse's present or future earning eapacity is impaired by periods of unemployment that were incurred during the marriage to permit the supported spouse to devote time to domestic duties."

186. See L. WeITZMAN, supra note 13, at 387 (stating that "if an older woman has little or no earning capacity, and has limited resources with which to buy another home at the time of the divorce, and if an equal division of fainily assets would require the sale of the family home, or if it 
to defer sale of the family home in order to permit the children to he there with their custodian. The legislature should consider amending the "family hoine award" statute to permit an older homenaker to occupy the home for a period of time under appropriate circumstances as part of the spousal support order. ${ }^{188}$ It does not seem fair, however, to remove the family hoine from the pool of community assets subject to equal division. The years following the enactment of the Family Law Act saw a sharp increase in real estate values in California which resulted in the dramatic appreciation of the family home im many cases. That appreciation may be the most valuable tangible asset acquired during the marriage. If apphication of the equal division mandate requires sale of the home in a particular case, by definition there are insufficient offsetting assets to permit its award to one spouse. To oumt the family home from the property available for ultimate distribution would deprive the nonhomeinaking spouse of the value of the commumity investment and undercut the equal division rule.

Professor Mary Ann Glendon offers a more radical restructuring of marital property law upon dissolution. She proposes a "children-first" principle 189 that would distinguish between "inarital" property, available for equal division between the spouses in a childless marriage, and "family" property, appropriated to guarantee the financial security of children and their custodian after divorce, including the security of a spouse who has been econoumically disadvantaged by past child rearing. Glendon

would require an older housewife to 'trade' her interest in her husband's pension in order to retain the family home, then the law should be amended to allow an exphicit exception to the equal division rule to enable an older woman to retain the family home after divorce").

187. See supra text accompanying notes $134-35$.

188. S.B. 1750, Reg. Sess. 1986 would have amended CAL. CIV. CoDE $\S 4800.7$ (West Supp. 1987) to authorize a court to

reserve jnrisdiction and temporarily defer the sale of the family home where the adverse cconomic, emotional, and social impact on an older spouse in a inarriage of long dnration, which would result from the immediate loss of a long established family houne are not outweighed by econoimic detriment to the other spouse.

S.B. 1750 failed passage in the Senate Judiciary Committee. See CAL. SENATE DaILY J. 5564 (May 7, 1986). S.B. 1341, Reg. Sess. 1987-88, would repeal CAL. Crv. CODE $\S 4800.7$ and substitute a new CAL. Civ. CODE $\S 4700.10$ that would provide a "deferred sale of home order" to delay the sale and award the temporary exclusive use and possession of the family home to a custodial parent of uninor children or children for whon support is authorized under CAL. CIV. CODE $\S \S 196$ or 206, "in order to minimize the adverse impact of dissolution or legal separation on the welfare of the children." The bill contains a list of nine factors that the court must consider in determining whether to inake a deferred sale of home order, primarily designed to direct the court's attention to the child's school environnent, the child's psychological welfare, and the custodial parent's working and child care arrangements. The order would constitute a form of child support. The bill makes no provision, as did former S.B. 1750, for a temporary award of the right to occupy the family home to an older spouse even when no children hive there. This omission seems shortsighted: the court shonld also be given discretion to inake a deferred sale of home order as part of the spousal support award in certain cases.

189. See Glendon, supra note 156, at 1559. 
rests this proposition on the notion that having children "impresses a lien upon all of the parents' income and property to the extent necessary to provide for the children's decent subsistence" 190 during their minority. I do not disagree with this principle, and I appreciate the practical force of Glendon's further point that "child support, custody, spousal support and property division cannot be neatly separated froin each other in practice."191 It does not follow, however, that we should abandon the effort to achieve economic justice between the spouses. Instead, we should focus more precisely on the reason for each aspect of the financial order so that its justification is clear. The distinction between separate property and community property is well established in California law and should not be abandoned in interspousal distributions. ${ }^{192}$ The "children-first" principle can be recognized by the imposition of support obligations, mcluding the use of the family hoine, that may be satisfied from either community or separate property.

Important as it is, the "children-first" principle should not be implemented in ways that will prevent parents from rebuilding their own lives after divorce. ${ }^{193}$ Divorce, after all, is a legal declaration that frees both spouses to seek new relationships. The financial consequences of divorce may have a more severe immediate impact on women than on men, but over timie women are niore likely to experience an improved quality of life following divorce than are men. ${ }^{194}$ The no-fault philosophy, which Weitzman found to have a devastating effect on the standard of living in the households of women and their children one year after divorce, ${ }^{195}$ thus may be less detrimental when its impact is measured over a longer period of time. The financial settlement should have as its goal not only security for children, but also opportunity for growth for their parents. If judges are more concerned about preserving the ex-husband's freedom than providing for the wife's ability to restrucure her life, then spousal support laws should be amended to provide more exphicit guidance. ${ }^{196}$

190. Id.

191. Id. at 1560 .

192. I agree with Professor Carol Bruch and others that this distinction would be clarifted and property distribution hitigation simplified by repealing CAL. Crv. CoDE $\S 5118$ (West 1983) so that postseparation earnings of both spouses would be defined as community property until divorce or death. See Bruch, supra note 178, at 821-23.

193. Wisconsin's atteinpt to prevent the remarriage of noncustodial parents who could not demonstrate their financial capacity to comply with support orders for their children was struck down as an unconstitutional deprivation of the fundamental right to marry. Zablocki v. Redhail, 434 U.S. 374 (1978).

194. Wallerstein, Women After Divorce: Preliminary Report from a Ten-Year Follow-Up, 56 AM. J. ORTHOPSYCHIATRY 65, 68-70 (1986).

195. L. WEITZMAN, supra note 13 , at 339.

196. The Agnos Child Support Standards Act of 1984, see supra text accompanying note 146, provides an appropriate inodel. Another promising model is found in S.B. 1296, 1987-88 Reg. Sess., 
In addition, as I have suggested above, ${ }^{197}$ the opportunity cost of child rearing should be recognized by a special award. In this way, the economic disadvantage to women that is the frequent result of traditional marriage can be somewhat ameliorated at divorce, and a substantive, rather than a formal, equality made possible.

\section{CONCLUSION}

California's no-fault divorce law introduced a new concept into the state's family law in 1970. That concept posited an end to fault finding and to the perpetuation of financial penalties for marital misconduct. The addition of another concept-that women and men should be treated as equals by the law-produced legal changes that have irrevocably altered the institution of marriage and made impossible a unitary definition of the family. In the seventeen years that witnessed those fundamental changes, judicial implementation of the combined philosophies of no-fault divorce and equality between women and men proved inadequate in the context of financial settlements following marital dissolution. As Weitzman has shown in such dramatic detail, women and children have borne the brunt of the transition that took place in California's legal regulation of the family between 1970 and 1987. Further changes are required to prevent such unfortunate and unnecessary results, but a return to the family law of 1970 is not among them.

which would amend CAL. CIv. CODE $\S 4801$ to include the following declaration of legislative policy:

(a) The Legislature finds and declares that it is the public policy of this state that marriage is an equal partnership, that both spouses have contributed equally to any economic benefits accrued as a result of this partnership, and that both spouses are entitled to share economic benefits after separation or dissolution equally. Spousal support awards shall therefore be based on the standard of living established by the parties during the marriage; however, in marriages of long duration, spousal support should serve to equalize the standards of living in the households of both parties after separation or dissolution.

The bill would amend the list of circumstances to be considered in setting the spousal support award to carry out the new legislative policy. The bill fails, however, to define what the term "marriage of long duration" means. This omission should be rectified. Although ambiguity in the length of a marriage of "long duration" can perhaps be tolerated in judicial opinions, a statute that purports to set forth a new approach to spousal support should be more precise.

197. See supra text accompanying notes 177-85. 
